\title{
Threats and the active protection of birds in a riverbed: postulates for the strategy of the preservation of the middle Vistula River avifauna
}

\author{
Dariusz Bukaciński*, Monika Bukacińska, Arkadiusz Buczyński \\ Instytut Ekologii i Bioetyki, Wydział Filozofii Chrześcijańskiej \\ Uniwersytet Kardynała Stefana Wyszyńskiego w Warszawie \\ ul. Wóycickiego 1/3, 01-938 Warszawa \\ *d.bukacinski@uksw.edu.pl
}

\begin{abstract}
Over the past 34 years, threats to Charadriiform birds inhabiting islands in the Vistula riverbed, mainly gulls, terns and plovers, have changed considerably. While in 1985-1994 the main risks for their breeding were found to be flood waters, predation by the hooded crow Corvus corone cornix and the Eurasian magpie Pica pica, as well as, locally, uncontrolled livestock grazing, in 2005-2014 they were primarily predation pressure from the American mink Neovision vision and the red fox Vulpes vulpes and massive outbreaks of black flies Simuliidae. These threats led to a reproductive outcome of nearly zero and increased the mortality of adults in their breeding areas. As a result, there was a sharp decline in numbers of the majority of gull, tern and plover species nesting there. In 2015-2018, apart from mammalian predation, key threats included the pressure of feral cats and dogs and the growing presence of people on the islands. In a situation that may lead to the extinction of first the mew gull, Larus canus, and later other species of birds, in 2005-2006, we began the active protection of endangered species on the middle Vistula River islands. This effort included (a) reducing the number of American minks and red foxes, (b) neutralising the presence of predators and livestock at the nesting sites with electric fences and the use of incubators and dummy eggs and (c) restoration of the nesting habitat, as well as, in the case of mew gulls, (d) increasing the genetic diversity within colonies. The most important demand is the conducting of the active protective measures in a comprehensive way and continuously for at least five years (until 2023), optimally throughout the decade (2019--2028). In addition, it will be also necessary to carry out wild life monitoring in this area. The other important task for the coming years will be to oppose plans for extensive engineering in the middle section of the river, which will irreversibly destroy this unique ecosystem.
\end{abstract}

\section{Keywords}

middle Vistula River, gulls and terns, active protection

\section{Introduction}

The Vistula river is one of the last large rivers in Europe that has preserved the features of a natural lowland river in a vast area. Lack of a permanent, comprehensive hydro-technical regime in the valley and the associated braided nature of the bed in the middle part of the Vistula create habitats, which are now very difficult to find in the Western Europe. These are primarily islands 
and sandy shoals, steep riverbanks and old willow-poplar riparian forests in the valley. The uniqueness of this environment stems from the high species diversity of avifauna (over 16o bird species, Chylarecki et al. 1995 Bukaciński 2010), but first of all from the presence of species characteristic for the almost natural large lowland rivers.

The core of the middle Vistula riverbed avifauna consists of Charadriiform birds, including several species of gulls, terns and plovers inhabiting mainly islands and sandy shoals in the riverbed (Bukaciński and Bukacińska 1994, 2008, 2015a, Bukaciński et al. 1994a, 2017, Bukaciński 2010). The place is absolutely unique for the mew gull Larus canus and the little tern Sternula albifrons maintaining here over $80-85 \%$ and $70-75 \%$ of the Polish breeding population, respectively. It is also a key place for the common tern Sterna hirundo, the Mediterranean gull Ichthyaetus melanocephalus, the ringed plover Charadrius hiaticula and the oystercatcher Haematopus ostralegus, being a breeding ground for at least $25-35 \%$ of the country total number. It is slightly less important for the little ringed plover Charadrius dubius and the black-headed gull Chroicocephalus ridibundus, supporting annually around $10-15 \%$ of the breeding population of each species (Chylarecki et al. 1995, Sikora et al. 2007, Wilk et al. 2010, Bukaciński and Bukacińska 2015a).

A natural consequence of the accumulation a large part of the breeding population in one place is the crucial impact of their fate (breeding outcome, adult survival, etc.) on the status of the species over the country. This is the case for the aforementioned species, in most of which (except the Mediterranean gull and the oystercatcher) a clear downward trend in the Vistula valley has been visible for last decades. Definitely the most disturbing situation is observed for the mew gull, which number decreased in this place over the past quarter of a century by nearly $80 \%$ (from 3500-4300 pairs to 700-900 pairs, in 1988-1993 and 2012-2018, respectively), accompanied by very bad population rates (high mortality of adults, breeding outcome close to zero) (Bukaciński et al. 1994a, 2017, Buczyński 200o, Bukaciński, Bukacińska 2003, 2007a, 2008, 2015a, Różycki 2014, Chylarecki et al. 2018, Bukaciński et al., unpubl. data). The more or less steady decline in numbers was recorded in last three decades (1993-2018) also for the other core riverbed bird species, from $15-25 \%$ for the ringed plover and the common tern and $20-25 \%$ for the little tern to $30-50 \%$ for the little ringed plover and the black-headed gull, accompanied by low reproductive success (Bukaciński et al. 1994a, 2007, 2017, Keller et al. 1998, 1999, Antczak 2007, Bukaciński, Bukacińska 2007b, 2008, 2015a, Chylarecki 2007, Drzyzga 2015, Bukaciński \& coworkers, unpubl. data). Although their status has not been yet disastrous, the observed trends give a reason for concern about the future of these species on their key breeding area.

\section{The main threats for breeding Charadriiform birds: changes during the last 34 years}

In the years 1985-1994 the most important limiting factors for breeding gulls, terns and plovers and other waders included weather conditions (usually sudden temperature drops in April and May, strong insolation or sand storms), frequent and high floods and bird predation, largely by the hooded crow Corvus corone cornix and the Eurasian magpie Pica pica, locally also uncontrolled livestock grazing, mostly cattle and to a lesser extent, horses and sheep (Table 1, Bukaciński and Bukacińska 1994, 1995, Chylarecki et al. 1995). In the 1990s, a completely new threat unknown to Vistula birds has appeared - massive outbreaks of black flies (blood-sucking dipteran from the Simuliidae family). Although they usually occurred only two or three weeks, between the half of May and the first decade of June, they caused extremely high breeding failures. Parents deserted their nests during the incubation stage and there was a high chick mortality rate observed, especially 
in first days of their life. Black flies caused also the increased mortality of adult gulls on breeding grounds (Bukaciński and Bukacińska 1997, 2000, 2008, 2015a). Whereas in the 1990s the largest losses in nests of gulls, terns and plovers were usually caused by spring floods, in the first half of the 1990 s the relatively most important factor limiting breeding outcome, especially in gull colonies, was mass occurrence of black flies (Table 1).

The composition of threats faced by ground nesting birds in the riverbed and their importance changed completely during the next decade (1995-2004). While up to 1999, black fly outbreaks appearing more frequently and more massively constituted the most considerable danger as well as large floods, locally also livestock grazing, in the years 2000-2004, absolutely the key threat for both adults and their offspring (next to the black-fly outbreaks), was the rapidly increasing pressure of the American mink Neovision vision and the red fox Vulpes vulpes (Table 1, Bukaciński and Bukacińska 2001, 2003, 2015a, Bukacińska and Bukaciński 2004a, 2004b, 2004c, Bukaciński et al. 2012). As a result, the breeding success of gulls and terns nesting on the Vistula islands was none or close to zero, and the mortality of adults was high on the previously unrecorded rate (Buczyński 200o, Bukaciński and Bukacińska 2001, 2008, 2015a, Bukaciński et al. 2012).

In the years 2005-2014 the most important differences regarding the composition of threats to island avifauna included: (1) constantly growing pressure of the American mink and red fox, reinforced by increasing presence of the raccoon dog Nyctereutes procyonoides and first signs of colonization by another alien invasive predatory mammal - the raccoon Procyon lotor, (2) noticeably lower pressure of the black fly outbreaks and livestock grazing (slow reduction in cattle and horse breeding) than in the years 1995-2004, (3) locally significant increase in a predation of the northern goshawk Accipiter gentilis and the
Eurasian eagle-owl Bubo bubo (on chicks and adult birds) alongside with more or less constant pressure of crows and magpies, (4) much more dynamic loss of optimal breeding habitats for terns and the mew gull due to a failure of livestock grazing, (5) growing activity of hydro-technical measures aimed at rebuilding, renovation and increasing a number of small transverse and longitudinal infrastructure on the river (weirs, groynes, bank protection structures, etc.), (6) presence of tourists on islands and sandy shoals, especially motorists on quads, motorcycles and off-road vehicles, growing rapidly every year, and (7) feral dogs and cats appearing increasingly on the islands in the riverbed (Table 1, Bukaciński and Bukacińska 2007a, 2007b, 2008, 2015a, Bukaciński et al. 2007, 2011, 2012, 2013, 2015a, Drzyzga 2015, Kot et al. 2017, Pikulska 2017).

The last four years (2015-2018) are characterized by more stable and on average lower water level in the middle Vistula river in April-June than in previous years. As a result, the reproductive failure caused by floods is on average the lowest for 30 years. However, long periods of hydrological drought also generate unfavourable and dangerous phenomena for birds. They accelerate a succession of vegetation on islands, thus reducing the area of optimal breeding habitats, especially for terns and the mew gull. Principally, however, they facilitate penetration of islands by people (anglers, campers, motorized tourism, including quads, motorcycles and off-road vehicles) and the red fox, stray dogs and feral cats. The reproductive failures caused by these factors are increasingly common, which means that these threats have already been among the most important (Table 1, Bukaciński, Bukacińska 2015a, Bukaciński et al. 2015a, Drzyzga 2015, Jaszewski 2016, Grabowska 2017, Kot et al. 2017, Pikulska 2017). The mammal predation is still a key risk for both adult birds and their offspring. It is worth noting, however, that during the last decade, a reduction of the American 


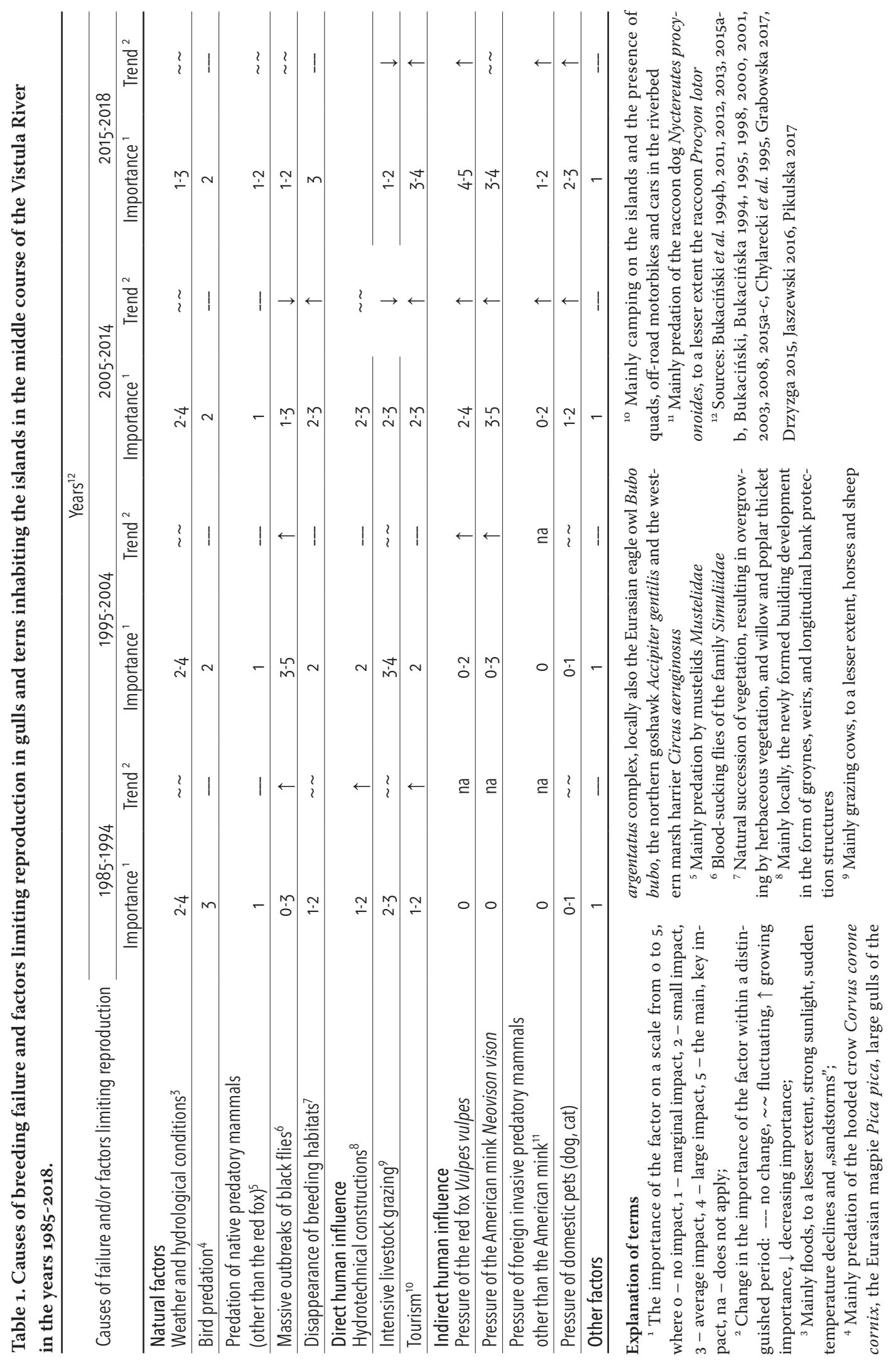


mink numbers in the middle Vistula valley (details below) has made the pressure of the red fox a relatively greater threat to birds than of the American mink (Table 1, Pikulska 2017, Bukaciński \& coworkers, unpubl.).

All the above-mentioned limiting factors are common for most of the Vistula Charadriiform birds, and certainly for all species of gulls and terns inhabiting islands in a riverbed. In the case of the mew gull we are dealing with another important phenomenon that adversely affects reproduction, related both to the lifehistory characteristics of this species (high natal philopatry, nest-site tenacity and mate fidelity, Bukaciński, Bukacińska 2003, 2015a) as well as the rapidly decreasing number of pairs in breeding colonies. It is a relatively low genetic diversity within a population (Bukaciński et al. 200o). It leads to increased unhatchability and low immunity of hatchlings (Buczyński 20oo, Bukaciński and Bukacińska 2003, 2008, 2015a, Spottiswoode and Moller 2004).

\section{Active protection of the endangered avifauna in a riverbed}

Due to the fact that a strong pressure of predatory mammals, to a lesser extent also massive black fly outbreaks and fast overgrowing of optimal breeding habitats has led to zero reproductive success and high mortality of adults (the first two factors) and the potentially increasing shortage of good nesting sites, it was known that without active protection of the most endangered species their further presence in a middle course of the Vistula will be seriously threatened in next one or two decades. Taking this into account, in 2005 in cooperation with the Polish Society for the Protection of Birds (OTOP) and the Centre for Ecological Research, Polish Academy of Sciences in Dziekanów Leśny we started to search for effective methods of protecting birds against the above mentioned threats. In the years 2005-2011, as part of projects financed first by the
Small Grants Program GEF/SGP (2005-2006), and later by the EcoFund Foundation (2008-2010), we developed several original protective measures, the effectiveness of which we worked out first in the mew gull colonies, and later also in colonies of the black-headed gull and common tern. Thanks to these experiences, in the years 2011-2015 we were able to coordinate a comprehensive OTOP project entitled "Active protection of endangered species of avifauna islands in the area of the middle Vistula river: continuation" (POIS.05.01.00-00-325/10.00) co-financed by the European Union from the European Regional Development Fund under the Infrastructure and Environment Programme and funded by the National Fund for Environmental Protection and Water Management. It covered an area of over $100 \mathrm{~km}$ of the river, where active protection measures concerned not only the mew gull, the black-headed gull and the common tern, but also the little tern, the oystercatcher, the ringed plover and little ringed plover. A detailed description of these activities and the time-space schedule of the program is presented in a separate paper (Bukaciński 2015).

\section{Reducing the American mink and the red fox numbers in a river valley}

The most effective method reducing the number of American minks in the Vistula valley is trapping in live traps, and then euthanasia of captured animals. Our experience shows that if only traps stand in places visited by minks, the effectiveness of catches is high. Shooting of this alien invasive species is quite inefficient. Although it is significantly cheaper and easier to implement than trapping, it is completely insufficient when the goal is the methodical, long-term and as extensive as possible reduction of the American mink over a large area.

It is best to catch the American mink in wooden and wire-type cage traps, with an automatic locking mechanism and a bait inside a trap (Photos 1-3). Definitely the 


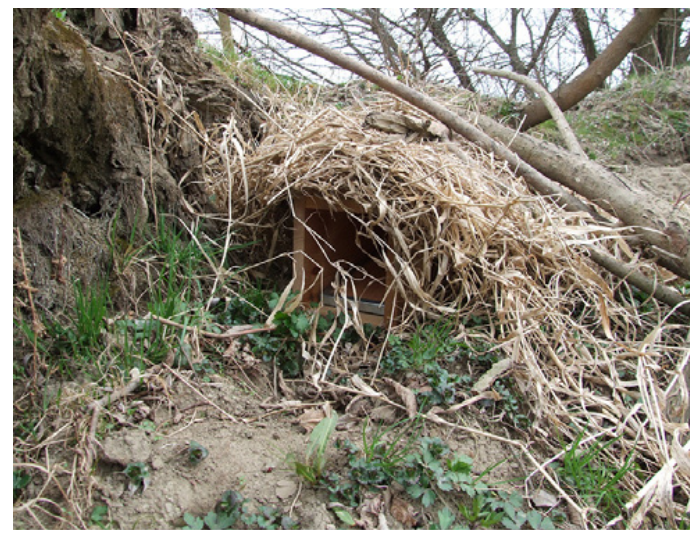

Photo 1. Under the conditions of the Vistula river traps for the American mink Neovison vison should be set up along both banks of a river and islands in a mainstream, low and as close as possible to water

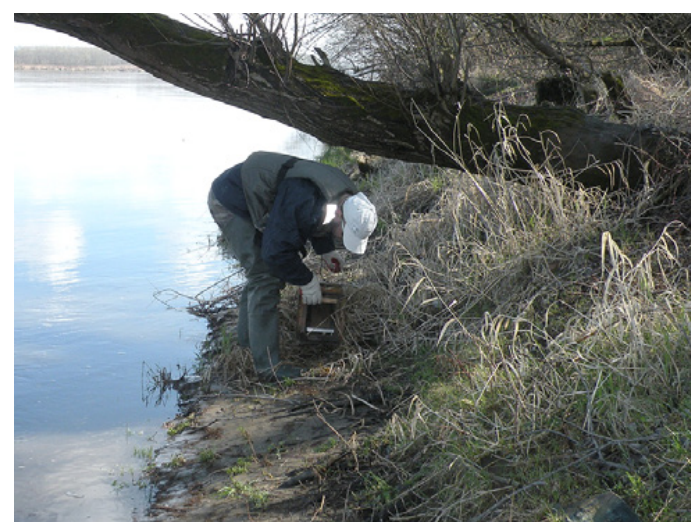

Photo 3. Although wooden traps for the American mink Neovison vison do not require solid masking (wood is a neutral element of odour well-known to the predator), covered with grass or other natural material (leaves, soil etc.) are better concealed, without arousing unnecessary interest of predators and above all significantly reduce the risk of theft

perfect bait to trap the American mink are raw fish (50-70 g), if possible - freshwater. Instead, pieces of defrosted fish (marine or freshwater), or poultry meat, may be inserted into a trap. Diagrams and technical details regarding the construction, dimensions of traps and types of trigger mechanisms of recommended models are

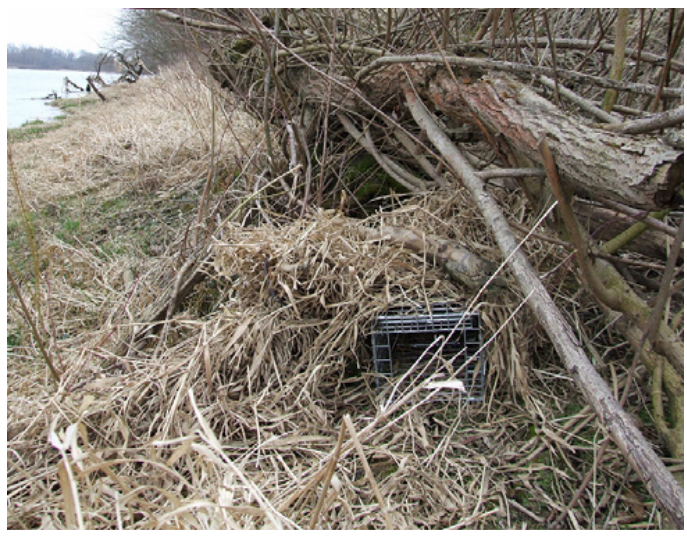

Photo 2. Wire traps for the American mink Neovison vison should always be masked as much as possible

included in another paper (Bukaciński 2015). Although wooden traps are much heavier, less resistant to weather conditions, wear out faster and are more often damaged by minks than wire-type cages, in the Vistula valley the optimal solution is a simultaneous use of both these models.

In open areas where there are no natural covers (like roots, wind-fallen trees, stones, hollows made by beavers, large amount of woody debris, etc.) and the material we mask the trap can be blown away by the wind, wooden traps work much better. To increase the effectiveness of trapping, Zalewski and Brzezinski (2014) recommended the use of an aromatic bait containing the secretion of the mink's anal glands.

Traps are situated along river banks, as close as possible to the border of water, preferably in hard to reach places, sheltered by branches, wind fallen trees or trunks (Photos 2-3). In the absence of natural covers or when using wire traps, it is necessary to mask the trap to make it invisible as much as possible (Photo 1). Hiding a trap increases the likelihood of a quick capture. It also reduces the risk of stealing, which occurs regularly, despite a placement of stickers with a contact phone number informing about the purpose of trapping. 
The resident individuals of the American mink use about 1-3 km of the river's course as their territory, controlling the shore about 600-900 $\mathrm{m}$ long at a time (Zalewski and Brzeziński 2014). With this in mind, in order to maximize the efficiency of trapping, a distance between neighbouring traps should not exceed 400-500 m. It should be remembered that the wider the river, the less often animals swim from shore to shore, occupying the area only on one side of a river. Therefore, on fragments of a river with islands and sandy shoals in a stream, where the width of a riverbed is greater than 250-350 $\mathrm{m}$, traps should be spread out along its banks and on banks of islands. A good practice, that facilitate finding camouflaged traps during the control, especially if the controlling team changes in following days, is to mark their location in the GPS. In traps, for which a predator did not enter for several days, a bait should be replaced every 2-3 days (the warmer the more often). In the case of wire traps, a bait is often eaten out by rodents (which easily enter and exit a cage) and/or corvids (which take food through the mesh). This creates the need to replenish a bait nearly during each control and potentially also reduces the effectiveness of trapping. Traps should be inspected once a day, which will shorten the time an animal is in. After catching, the animal should be sedated and put to sleep in the most humane way previously approved by the appropriate Local Ethical Committee (LKE). Such activities (as the others involving vertebrates) can only be carried out by authorized persons employed in institutions that have the permission from the National Ethical Committee to conduct animal experiments.

On the Vistula river year-round trapping of American minks works best. Although during the spring-summer season (AprilAugust) due to large amount of natural food in the environment (hence, baits are less attractive) the effectiveness of trapping is lower than in autumn or winter (SeptemberMarch), then conducting the activity in this period is not only that appropriate but even necessary. From May to July gulls and terns care for unfledged chicks and the pressure of American mink females, which teach to hunt their offspring is particularly high. Mothers minks are very aggressive this time and chase away other individuals from their territory. As a result, trapping between May and July of every female is, likely, a guarantee of safety for the next few weeks for the birds nesting along at least 1-2 $\mathrm{km}$ of the river (current territory of each mink). The captures from August to October allow in turn to remove a large percentage of young, one-year-old individuals which disperse during this period. A detailed timespace schedule for the course of a single trapping session is described in Bukaciński (2015). In the years 2006-2016 we managed to remove several hundred individuals by this method. The average effectiveness of mink captures (successful trapping), after an earlier detection of their presence in a given place (tracks, faeces) was high and varied depending on the year from $25-35 \%$ in the spring/ summer to $70-85 \%$ in the autumn/ winter season (Bukaciński et al., unpubl.).

Reducing the number of the red fox (also the raccoon dog) can also be achieved by trapping and euthanizing. However, the great vigilance of this predator makes the effectiveness of this method much lower than in a case of the American mink. Therefore, we cannot use only this measure. At the same time, it is advisable (and even necessary) to conduct shootings. It is important to do it obligatory yearly (based on the opinion of the State Council for Nature Conservation and the decision of the Minister of the Environment), which significantly strengthens the overall reduction effect. Cooperation with local hunting clubs is very important. It will allow for correcting places and dates of the treatment to concentrate on especially endangered areas and to carry out the shooting regularly.

The method of fox trapping into live traps is analogous to that described for American 
minks. The differences are: (1) use of the wire-type cages of a larger size; (2) use of poultry meat, fat and eggs as a bait; (3) establishing traps further from the river, on a higher bank, and in April-July with a larger proportion of cages located on islands near a colony of gulls or terns, and (4) avoiding to leave human odour on a trap and a bait (it is necessary to wear disposable gloves). It should also be remembered that from April $1^{\text {st }}$ to May $31^{\text {st }}$, the red fox in Poland is under protection and any catches in this period must be preceded by obtaining an additional permit (except the necessary LKE permit) of the Minister of the Environment.

\section{Neutralizing the presence of predatory mammals and livestock on breeding grounds}

Not immediately, not everywhere, and not all mammalian predators can be effectively eliminated from the Vistula valley. It is therefore necessary to keep clutches and broods of threatened species against the pressure of these animals. As part of this activity, we propose to protect breeding grounds of the largest nest concentrations with electric fences. In places where nests are single or less clustered - we propose to

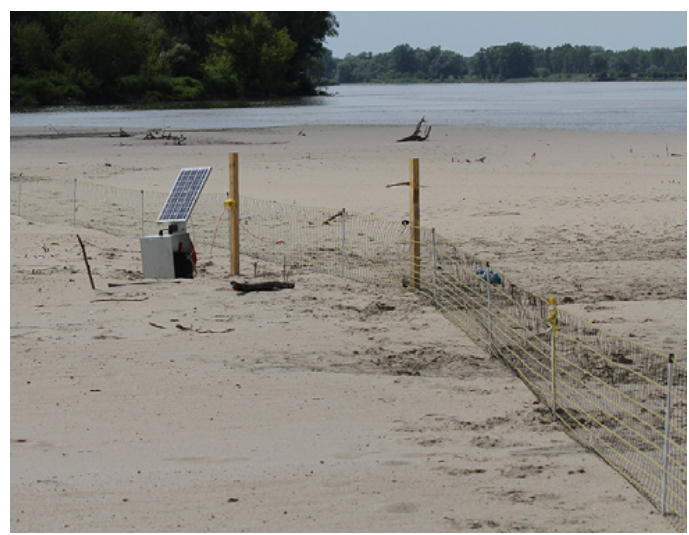

Photo 4. Electric fence of a height of $60 \mathrm{~cm}$ is usually sufficient to protect the Vistula colonies of gulls and terns. A good practice is to support power by solar panel, a necessity - the positioning of signs indicating that a fence is electrified put eggs to incubators while placing dummy wooden eggs in nests. Dummies should be painted so that they resemble the original eggs of a given species as most as possible.

Electric fences is a very effective form of the breeding area protection both against predatory mammals and livestock grazing on islands of the Vistula. However, they cannot be constructions that are commonly used in non-flooded areas for cow or horse control (a permanent single electrified wire or tape) (e.g. Śmietana 200o, Nowak et al. 2005). The models proposed by us are adapted to the prevailing conditions in a riverbed. It should be a light, relatively easy to assemble plastic electric net mounted on insulating stakes connected with the next net, which in the case of high water level can be quickly disconnected and folded for the immediate transport of all elements from islands to safe places outside a riverbed. In the Vistula riverbed, $60 \mathrm{~cm}$ high wire netting is quite sufficient, although in heavily overgrown places, especially when the area is strongly undulating, it is good to consider installing a grid system with a height of $120 \mathrm{~cm}$ (Photos 4-5). Details of the fence components, the method of their assembly and rules regarding monitoring and control

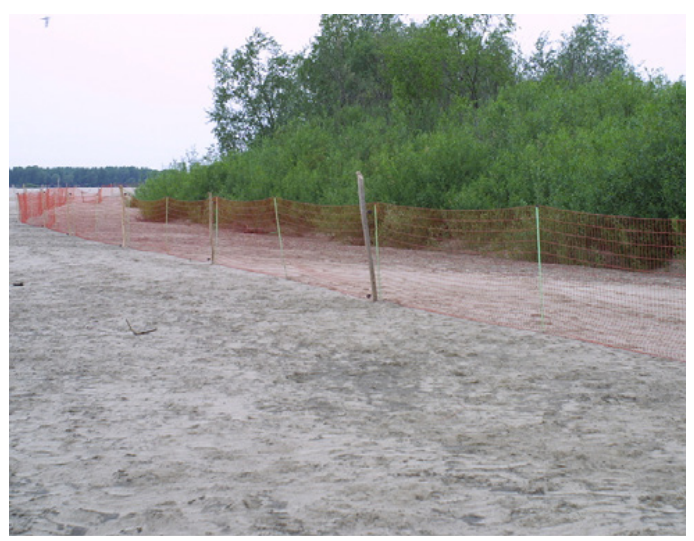

Photo 5. A fence of a height of $120 \mathrm{~cm}$ is only used in a case of a heavily overgrown and/or strongly undulating terrain 
of the operation of the entire system were presented in Bukaciński (2015). Generally, in addition to the set of wire meshes which can be connected and mounted on posts and / or insulators, the system protecting gull and tern nesting sites should obligatorily contain a battery, an energiser and an earth stake or spike (Photo 4). It is also necessary to install plates informing about the risk of electric shock. It is good but not necessary to support a battery with a solar panel (Photo 4). The battery discharges much more slowly then, and at the fairly sunny weather it operates continuously for 5-6 weeks. Due to the fact that low herbaceous vegetation acts as a very good insulator, it should be removed at least to the width of the meter on each side of a fence (Photo 6). When the fence surrounds a large area, it will be necessary to use a clearing saw, a trimmer or a chain saw. However, it has to be remembered that such activities should be carried out quickly, trying not to disturb the birds. We should check the voltage on a grid at least once every few days. At the most remote location from the battery, it should not be lower than 80o-10oo Volts.

The electric fence protects only nests with eggs and newly hatched chicks (up to 1-2 days of age). Mesh size is large enough

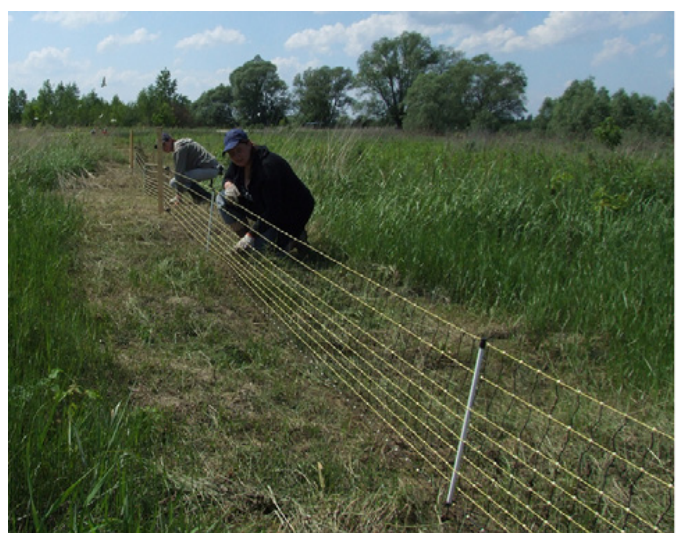

Photo 6. Since the vegetation is an excellent insulator strongly decreasing a voltage on a grid, it is necessary to remove all plants in close proximity to the fence (and the lowest grid line is never energized) that gull chicks up to 4-6 days old (and tern chicks and plovers much longer) can freely leave the electric fence. However, they are then exposed to both trampling by livestock and predation of mammals. This does not change the fact that for eggs of gulls and terns, the effectiveness of this treatment was complete. We have not found that ever since 2005, when we used this protective measure for the first time, predatory mammals or farm animals managed to force the fence under voltage. The solution, that works well in bird colonies at the Vistula islands, is an enrichment of the above described system with a poultry netting mounted inside an electric fence (Photo 7). In this way, also chicks are protected until they fledge. Due to this innovation, during the eleven years (2008-2018), we did not find a single case of death among protected chicks due to the trampling by livestock or from predatory mammals.

The second solutions we propose against mammalian predators involves the use of incubators and wooden dummy eggs (Photos 8-9). This activity is consistent with the previous one, strengthening its effect and particularly important for birds nesting at greater distances, and thus unguarded

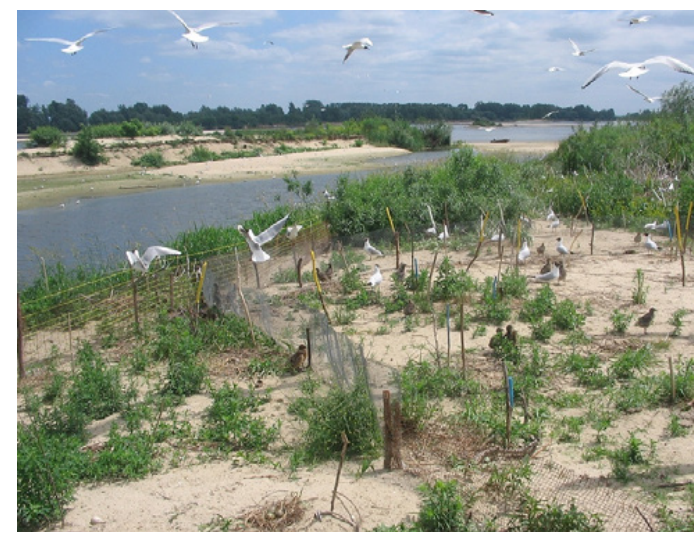

Photo 7. Mounting a poultry netting inside an electric fence can protect chicks until they will fledge 


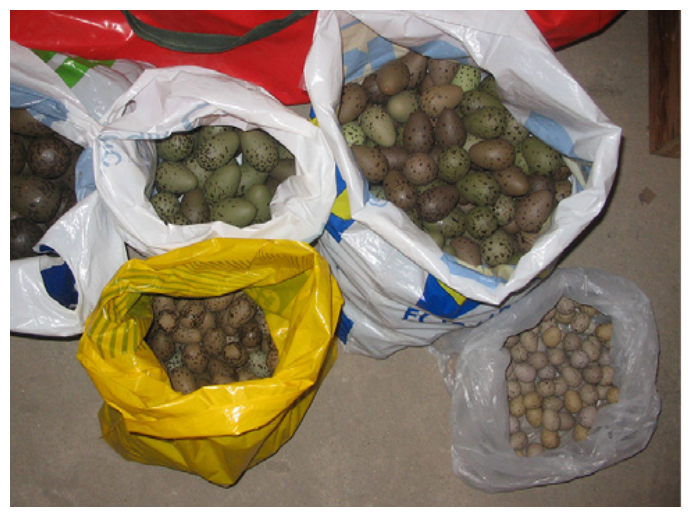

Photo 8. Wooden dummy eggs of gulls and terns prepared for putting into nests

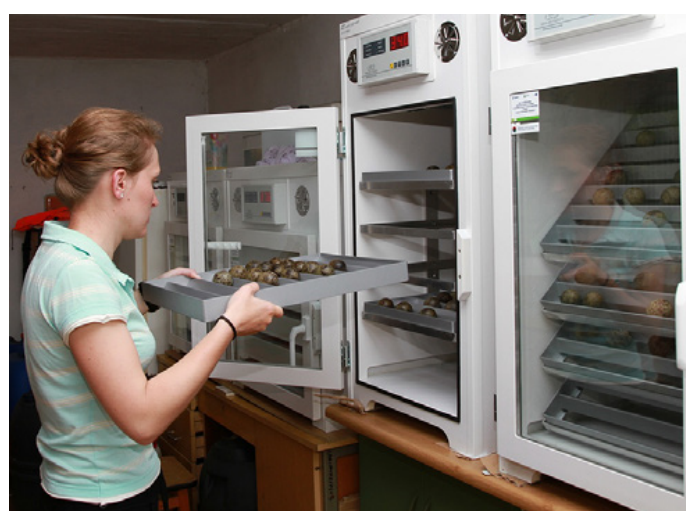

Photo 9. Clutches of the mew gull Larus canus, as well as of other species of gulls, terns and plovers are taken into incubators, where they are temporarily incubated

the same species, being in a similar stage of breeding.

The use of this method means that during the incubation stage eggs are not exposed to the predation of mammals, as well as crows and magpies. Moreover, usually the American mink and the red fox do not recognize artificial eggs as their potential food, and more rarely disturb adult birds on breeding grounds. Also during mass black fly outbreaks, temporary deserted nests with dummies are not exposed to losses. Our experience so far shows that the danger of rejection of dummy wooden eggs by gulls, terns and plovers is negligible. We have not found that the presence of dummies in a nest has ever caused the nest abandonment. Performing this procedure smoothly depends upon knowledge and some experience acquired over time. When one tries to use incubators for the first time, it is a good idea to consult and use the advice of professional breeders. It is also extremely important to carefully prepare dummy eggs (Photo 10), which reduces the risk of the nest abandonment, and to purchase professional incubators and hatchers.

The active protection of clutches involving the use of incubators and dummy eggs is innovative, fully original. We used it for the eggs should be placed into another nest of 


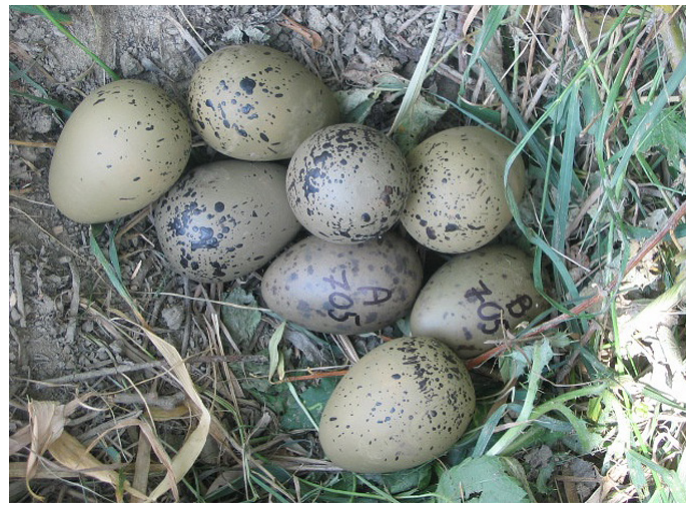

Photo 10. Well prepared dummies are not so easily distinguishable in a field from original eggs, thus they are also as often stolen by crows and magpies as original eggs of gulls and terns. In the picture, dummy and original eggs of the mew gull Larus canus (with numbers and letters on a shell)

first time in our projects for the protection of gulls and terns. The first tests were conducted in the years 2005-2006 in the mew gull colonies. Since 2008, this form of active protection has been used with great success for all species of gulls and terns protected by us, as well as both species of plover and the oystercatcher.

\section{Restoration of breeding habitats}

Considering both the extremely dynamic succession of vegetation on islands and the cultural background (legal and illegal grazing of livestock on islands in a riverbed), one should use two approaches simultaneously: graze livestock and cut saplings (mainly bushy and woody willow species Salix spp., poplars Populus spp. and box elder Acer negundo). The treatment should primarily cover places with previously high nest density and now abandoned by birds due to overgrowing, and islands that may potentially be attractive for endangered species of ground-nesting birds.

Rapid overgrowing of islands greatly limits the area of optimal breeding habitat for gulls and even more for terns. Moreover, it also significantly hinders successful breeding (too dense and high vegetation prevents easy movement of chicks). Grazing livestock is therefore very beneficial, and thus advisable. It should however be properly organised. In another case, the presence of farm animals on islands may lead to large failures, especially in colonial species (Bukaciński and Bukacińska 1995, 2001, 2015a).

In the last 13 years (2006-2018) we examined the effectiveness of grazing cows, horses, sheep and goats on the Vistula islands. Our experience suggests that the best is to maintain a mixed herd of goats and sheep. Then pasturing can be carried out almost all year round, also during breeding season of birds. They could be transported to islands at the beginning of April (in some years - already in the second half of March), and take back only in late autumn (OctoberNovember ). Sheep mainly eat grasses, goats, in addition to the herbaceous vegetation, very efficiently "clean" islands from seedlings and saplings of poplar and willow. Our observations show that islands where these animals are located are also less often visited by foxes. The presence of sheep and goats in the spring, even on islands with blackheaded gull colonies usually does not cause losses in nests. Goats and sheep actively avoid places with a large number of crying birds (black-headed gull colonies). The mew gull and terns breed in loose clusters and mainly on sand, where animals stay much less frequently, usually only when they go to drink water. In order to be sure that even occasional crushing of eggs will not occur, the largest nest clusters can be secured with electric fences. Details regarding selection of breeds and basic requirements of sheep and goats as well as grazing conditions of other livestock are presented in Bukaciński (2015). Regardless of which animals is pastured on the island, it is a good practice to hire a person who looks after the herd every few days and if necessary, takes an appropriate action. Such ungulates as the llama Lama glama, the alpaca Vicugna pacos, crossbreeds of both species with 
their wild ancestors - the guanaco Lama guanicoe and the vicuna Vicugna vicugna, or the donkey Equus asinus are the best in the role of a permanent shepherd of sheep and goats (Nowak and Mysłajek 2006, Web1). The additional advantage of these animals is that they feed on the same food as sheep and goats. Their presence on an island quite effectively protects sheep and goats against thieves and foxes or packs of feral dogs that can decimate herds of grazing livestock (Web-1, D. Bukaciński, own observations). However, it is important to employ only one llama, alpaca or donkey to care for a herd. The presence of several "shepherds" makes them stay in their own company, and consequently they are less vigilant (Nowak and Mysłajek 2006).

Manual mowing and sowing the thicket is a second activity that effectively exposes areas for breeding ground-nesting birds. This treatment also increases the number of attractive places for the mew gull, that prefers nesting in whorls or near a trunk of a cut bush. It also reduces the risk of predation by crows and magpies, using high branches as a hunting stand (Bukaciński 2015, Bukaciński and Bukacińska 2003, $2015 \mathrm{a})$. In order to strengthen an overall effect, it is good to coordinate the cutting operation with grazing. In summer or autumn, it would be necessary to remove the thicket and trees from islands (fragments of islands), and in the next year early in the spring introduce goats and sheep there. Animals browsing the regrowth of plants effectively accelerate the resettlement of these places by gulls and terns.

Manual cutting of herbaceous vegetation with the use of brush cutters or trimmers equipped with cutting blades (not a cord) is not very complicated, and at the same time it successfully prepares habitats for breeding ground-nesting birds, mainly both species of plovers, the mew gull, the common tern and the northern lapwing Vanellus vanellus, which quickly settles exposed areas. Removing thicket and trees using a chainsaw requires much experience and the succeeding an appropriate course. Performing such a procedure even on large areas is not very time-consuming. The preparation of truncated biomass in stacks, allowing its subsequent taking of the island requires a lot more time. The transport of biomass from an island is also a major logistical challenge. One can do this by renting a barge. In the late-summer period, however, water level of the Vistula river is usually low, which prevents water transport. Another solution is transporting biomass ashore using special tractors, most often used for forestry works (e.g. forwarders) (Photos 11-12). However, that it is an expensive, logistically complicated and risky process (of drowning the equipment).

The end result, however, is difficult to overestimate (Photos 13-14). Sites (islands), which for many years were not occupied by birds at all, in the next were again an attractive breeding habitat for several species (lapwings, redshanks Tringa totanus, common sandpipers Actitis hypoleucos, mew gulls, black-headed gulls, common terns, and little ringed plovers) .

\section{Increasing genetic diversity in the mew gull colonies}

The mew gull is a highly conservative species characterized by high natal philopatry, nestsite tenacity and mate fidelity (Bukaciński, Bukacińska 2003, 2015a). Species with such behavioural patterns are always more exposed to inbred depression than those more mobile. The situation becomes even more complicated when the number of conservative species in a given area begins to drop rapidly, and survival of chicks that could recruit the population in the future is permanently close to zero. This leads to a decrease in genetic diversity of such a population. In a consequence adults are less and less vital and embryos and chicks much less resistant to adverse environmental conditions (cold, insolation, rain, etc.) and diseases. The scenario presented above has been observed in the last two decades in the Vistula colonies of the mew gull. The high 


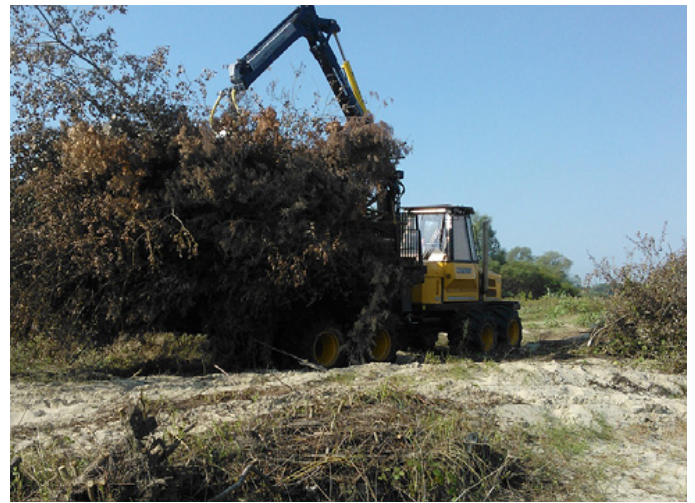

Photo 11. After drying, biomass should be removed from an island, for example using special tractors (so-called forwarders)

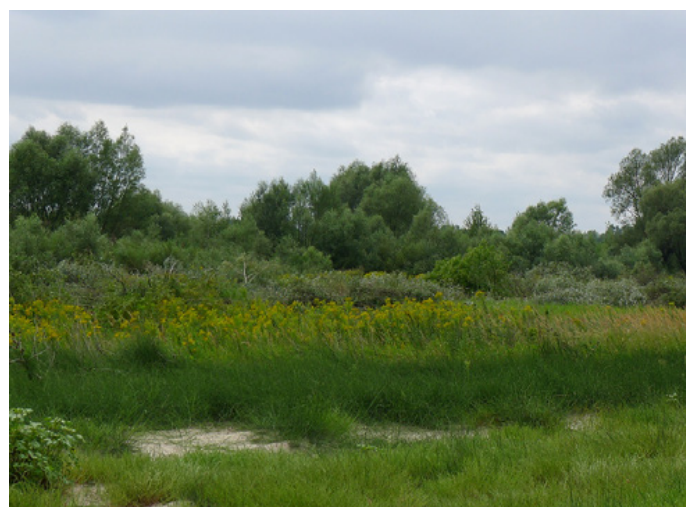

Photo 13. A fragment of an island before the clearing treatment

genetic similarity between birds in a colony and between partners within a pair made the hatchability on the middle Vistula river low (Bukaciński et al. 200o, Bukaciński and Bukacińska 2003, 2015a, Spottiswoode and Moller 2004).

Of course, a key threat, the neutralization of which determines continued existence of the species on the Vistula is a predation of American minks and red foxes. However, this does not change the fact that inbred depression is probably a serious problem of Vistula colonies of the mew gull, unfortunately much harder noticeable (and thus easier to overlook) than predation.

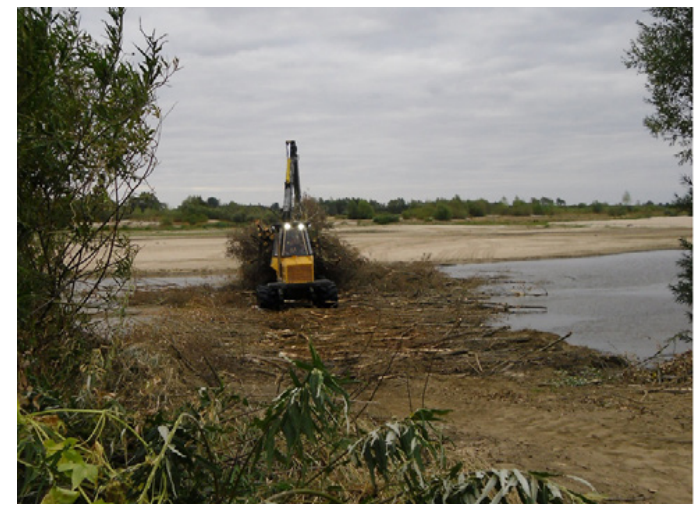

Photo 12. When removing biomass from an island the most complicated and dangerous is to carry it through the ford (shallow passage of a riverbed with a hard bottom)

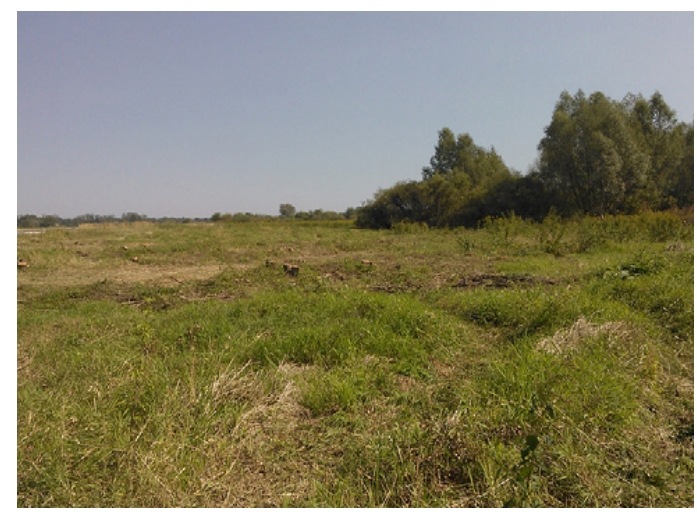

Photo 14. This is the same place as in Fig. 13, after cutting of trees and thickets and biomass removed outside a riverbed

If we now do not attempt to reverse or at least slow down this process, the decreasing number of mew gulls will enlarge effects of low genetic diversity, no matter how fast we can stop or at least significantly reduce the pressure of mammalian predators .

The method of increasing a gene pool within individual colonies is based on the mutual exchange of clutches between nests far from each other not less than a dozen (optimally - several dozen) kilometres. However, they must be clutches from the other Vistula population, so as not to lose the specific, unique life-history characteristics of mew gulls inhabiting 
this environment (Bukaciński et al. 2000, Bukaciński and Bukacińska 2003, 2015a). Mutual exchange of clutches is an effective method of increasing a gene pool of populations in rare, endangered and/or highly conservative species (Westmeier 1991, Frantham et al. 2010). The basis, however, is monitoring a genetic relatedness (or genetic similarity) between birds from different places. Otherwise, it may happen that, instead of increasing, we will reduce a genetic diversity of local populations (Haig et al. 1990, Sruoga et al. 2006). These can be measured by analyses of DNA isolated from blood, taken from adult gulls or chicks in a standard manner from a metatarsal vein (Photos 15-16). This requires the acquisition of different skills - catching gulls on nests, taking and preserving blood, making DNA analyses, and interpreting molecular analysis results. One must also have an access to the laboratory (or a budget for outsourcing analyses). Necessary is to obtain the appropriate permits from the Local Ethical Committee, the Regional Directorate for Environmental Protection and the General Directorate for Environmental Protection (details in Bukaciński 2015).

\section{Postulates for the avifauna protection strategy in the middle Vistula riverbed}

All the protective activities presented above concern long-lived birds, matured only in 2-3 (terns, plovers) or 3-4 years (gulls), which have only one clutch per year consisting of 1-3 eggs (gulls, terns) or 2-5 eggs (plovers, the oystercatcher) (Bukaciński and Bukacińska 2003, 2015a). These biological characteristics mean that we are dealing with species, the number of which falls much faster (in the situation of deadly threats) than it grows (e.g. as a result of protective actions). Therefore, the most important postulate, crucial for a success of the entire program of protection of these endangered riverbed species is to carry out active protective measures in a comprehensive manner, and most importantly continuously for at least five years (until 2023), if possible optimally for ten years

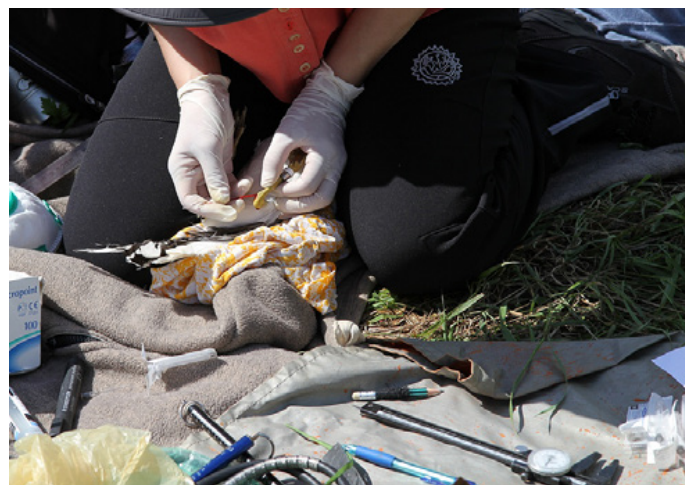

Photo 15. Blood for analyses is collected from a meta-tarsus vein with a capillary

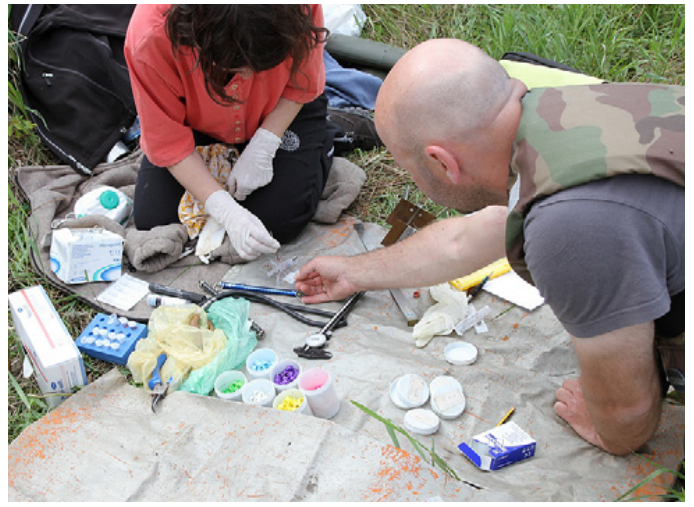

Photo 16. Blood for kinship analyses of birds is conserved in the Eppendorf tubes with a special buffer (in a blue sponge on the photo). To monitor the health of birds we leave two or three drops of blood on a microscope slide to take a smear

(2019-2028). The most important task in this period will be to ensure the highest possible reproductive success and to minimize the mortality of adult birds. The implementation of this objective will have a critical influence on a recruitment by young birds to the $\mathrm{Vi}$ stula population in the future and thus on the number of birds starting reproduction in subsequent years. With this in mind, a comprehensive program of active protection of a riverbed avifauna should include primarily reduction of numbers and neutralization a presence of American minks, red foxes and raccoon dogs (and in the near future 
also raccoons and perhaps golden jackals Canis aureus) in close proximity of the most important breeding grounds, and in a case of the mew gull - also a treatment that maintains high genetic diversity of birds within colonies. A detailed spatial and temporal schedule of such activities in the middle $\mathrm{Vi}$ stula valley is presented in Bukaciński (2015).

A very important element of the protection strategy is monitoring of its effects. This is the second key postulate without which the implementation of protection measures would be in limbo. The evaluation of effects should be extensive and include both monitoring of the number and distribution as well as the breeding ecology (including death rates of adults on breeding grounds, size and causes of breeding failures at the incubation stage, hatching success and chick survival) of the most important species of a riverbed avifauna. Details on evaluation methods are presented in other papers (Bukaciński 2015, Bukaciński and Bukacińska 2015b, 2015c, Bukaciński et al. 2015b, Chylarecki 2015a, 2015b, Zielińska et al. 2015). It is also necessary to monitor the number and distribution of predatory mammals based on tracks, droppings and other signs. People performing this task should be able to recognize traces left by American minks, red foxes, raccoon dogs, and raccoons. It will also be advisable to recognize signs of the golden jackal, the European pine marten Martes martes, the beech marten Martes foina, the European polecat Mustela putorius and the domestic cat Felis catus. Angiel and Bukaciński (2015) or any field guides to European predatory mammal tracks and signs can help here. Methods of the mammalian predator monitoring and the spatial and temporal schedule for this activity in the middle Vistula valley are presented in Bukaciński (2015). While monitoring a key threat to birds of the Vistula valley (predatory mammals), one must not forget about other dangers, which may increasingly limit the number and breeding outcome of the Vistula water birds. We propose to pay attention primarily on feral dogs and cats, appearing increasingly in the middle Vistula valley. Especially the presence of domestic cats, which could be just as effective as the American mink in causing huge reproductive failures, is very distressing (Table 1). The next threat is the ever-growing number of people on islands, especially motorized ones (Table 1, Bukaciński et al. 2015a). Quads and, to a lesser extent, off-road vehicles and endure motorcycles appearing in spring and summer on breeding grounds of gulls and terns often pass through bird nests, sometimes they also cause birds to abandon eggs or broods. The presence of people on islands also lead to the destruction of protective actions (people take dummies from nests, steal traps, nets, batteries and solar panels, break electric fences).

The last postulate for the next decade is not directly related to the active protection of endangered species. It is a care for preservation of the whole unique ecosystem of a large lowland river valley, with old riparian forests along floodplains, islands and sandy shoals in a riverbed and steep banks, an environment for an extremely diverse natural world. It is necessary to carry out informational, educational and promotional activities that will lead to abandonment of the ever-emerging plans for the extensive regulation of a middle section of the Vistula river. The implementation of these engineering ideas would irrevocably destroy the natural Vistula, with its priceless natural values, but also with landscape, social and cultural values (Angiel and Bukaciński 2015).

\section{Acknowledgments}

We are very grateful for the heavy field work of many people cooperating with us during the research and protective activities in the middle Vistula channel. Special words of thanks go to (in alphabetical order): Magdalena Block, Robert Dejtrowski, Martyna Drzyzga, Milena Grabowska, Bartosz Jaszewski, Ewelina Mastalerz, Joanna Ostrowska, Aneta Pikulska, Bartosz Popis, Andrzej Różycki, Marek Sawicki and Agata Urbanek. 


\section{Bibliography}

Angiel J., Bukaciński D., 2015, Oblicza Wisty. Przewodnik warszawski dla tropicieli przyrody, wyd. STOP, Warszawa.

Antczak J., 2007, Rybitwa białoczelna Sternula albifrons, in: Sikora A., Rohde Z., Gromadzki M., Neubauer G., Chylarecki P. (eds), „Atlas rozmieszczenia ptaków lęgowych Polski 1985-2004", Bogucki Wyd. Nauk., Poznań, 244-245.

Buczyński A., 200o, Straty jaj w koloniach mewy pospolitej (Larus canus) na Wiśle - znaczenie trzeciego jaja $w$ legu, Praca magisterska, Zakład Ekologii UW, Warszawa.

Bukacińska M., Bukaciński D., 2004a, Larus ridibundus (L., 1766) - śmieszka, in: Gromadzki M. (ed), „Ptaki (część II). Poradniki ochrony siedlisk i gatunków Natura 2000 - podręcznik metodyczny”, Wyd. Ministerstwa Środowiska, Warszawa, T.7, 160-165. Bukacińska M., Bukaciński D., 2004b, Larus canus (L., 1758) - mewa pospolita, in: Gromadzki M. (ed), „Ptaki (część II). Poradniki ochrony siedlisk i gatunków Natura 2000 - podręcznik metodyczny", Wyd. Ministerstwa Środowiska, Warszawa, T. 7, 166-17o. Bukacińska M., Bukaciński D., 2004c, Sterna hirundo (L., 1758) - rybitwa rzeczna, in: Gromadzki M. (ed), „Ptaki (część II). Poradniki ochrony siedlisk i gatunków Natura 2000 - podręcznik metodyczny", Wyd. Ministerstwa Środowiska, Warszawa, T. 7, 186-191. Bukaciński D., 2010, Dolina Środkowej Wisty, in: Wilk T., Jujka M., Krogulec J., Chylarecki P. (eds), "Ostoje ptaków o znaczeniu międzynarodowym w Polsce", Wyd. OTOP, Marki, 297-299.

Bukaciński D., 2015, Strategia czynnej ochrony zagrożonej awifauny wysp środkowej Wisty: podręcznik najlepszych praktyk, Wyd. OTOP, Marki.

Bukaciński D., Bukacińska M., 1994, Czynniki wptywajace na zmiany liczebności i rozmieszczenie mew, rybitw i sieweczek na Wiśle środkowej, Notatki ornitologiczne, 35, 7997.

Bukaciński D., Bukacińska M., 1995, The factors limiting breeding success in the Blackheaded Gull (Larus ridibundus) in different habitat types on the middle course of the Vistula River, Poland, Archive für Hydrobiologie, 101, Large Rivers, 9, 221-228.

Bukaciński D., Bukacińska M., 1997, Masowy pojaw meszek Simulidae przyczyna strat w legach $w$ koloniach mewy pospolitej Larus canus na środkowej Wiśle, Notatki ornitologiczne, 38, 167-168.
Bukaciński D., Bukacińska M., 1998, Production of erythristic eggs by the Black-headed Gull in Poland, Wilson Bulletin, 109, 177-182.

Bukaciński D., Bukacińska M., 200o, The impact of mass outbreaks of black flies (Simuliidae) on the parental behaviour and breeding output of colonial common gulls (Larus canus), Annales Zoologici Fennici, 37, 43-49.

Bukaciński D., Bukacińska M., 2001, Zagrożenia ptaków gniazdujacych na Wiśle środkowej, in: Kot H., Dombrowski A. (eds.), „Ochrona Fauny Niziny Mazowieckiej", MTOF, Siedlce, 117-128.

Bukaciński D., Bukacińska M., 2003, Larus canus Common Gull, in: Parkin D. (ed.), "Birds of Western Palearctic, Update 5”, Oxford Univ. Press, Oxford.

Bukaciński D., Bukacińska M., 2007a, Mewa pospolita Larus canus, in: Sikora A., Rohde Z., Gromadzki M., Neubauer G., Chylarecki P. (eds), "Atlas rozmieszczenia ptaków lęgowych Polski 1985-2004", Bogucki Wyd. Nauk., Poznań, 230-231.

Bukaciński D., Bukacińska M., 2007b, Rybitwa rzeczna Sterna hirundo, in: Sikora A., Rohde Z., Gromadzki M., Neubauer G., Chylarecki P. (eds), "Atlas rozmieszczenia ptaków lęgowych Polski 1985-2004", Bogucki Wyd. Nauk., Poznań, 242-243. Bukaciński D., Bukacińska M., 2008, Threatened bird species of the middle Vistula River islands: status, necessity for protection and proposed activities, in: Uchmański J. (ed), “Theoretical and applied aspects of modern ecology”, Wyd. UKSW, Warszawa, 219-239.

Bukaciński D., Bukacińska M., 2015a, Kluczowe gatunki ptaków siewkowych na środkowej Wiśle: biologia, ekologia, ochrona $i$ występowanie, Monografie, Wyd. STOP, Warszawa.

Bukaciński D., Bukacińska M., 2015b, Rybitwa rzeczna Sterna hirundo, in: Chylarecki P., Sikora A., Cenian Z., Chodkiewicz T. (eds), „Monitoring ptaków lęgowych. Poradnik metodyczny", Wyd. GIOŚ, Warszawa, 299-306.

Bukaciński D., Bukacińska M., 2015c, Mewa siwa Larus canus, in: Chylarecki P., Sikora A., Cenian Z., Chodkiewicz T. (eds), „Monitoring ptaków lęgowych. Poradnik metodyczny", Wyd. GIOŚ, Warszawa, 286-292.

Bukaciński D., Cygan J., Keller M., Piotrowska M., Wójciak J., 1994a, Liczebność i rozmieszczenie ptaków wodnych gniazdujących na Wiśle Środkowej 
zmiany w latach 197393, Notatki ornitologiczne $35,547$.

Bukaciński D., Rutkowska A., Bukacińska M., 1994b, The effect of nesting Blackbacked Gulls (Larus ridibundus) on the soil and vegetation of a Vistula River island, Poland, Annales Botanici Fennici, 31, 233243.

Bukaciński D., Bukacińska M., Lubjuhn T., 200o, Adoption of chicks and the level of relatedness in common gull, Larus canus colonies: DNA fingerprinting analyses, Animal Behaviour, 59, 289-299. Bukaciński D., Betleja J., Zieliński P., 2007, Śmieszka Larus ridibundus, in: Sikora A., Rohde Z., Gromadzki M., Neubauer G., Chylarecki P. (eds), "Atlas rozmieszczenia ptaków lęgowych Polski 1985-2004", Bogucki Wyd. Nauk., Poznań, 228-229. Bukaciński D., Bukacińska M., Buczyński A., 2011, Awifauna wodno-błotna środkowej Wisty w okresie legowym: wptyw działalności człowieka na rozmieszczenie, liczebność i bogactwo gatunkowe, Studia Ecologiae et Bioethicae, 9, 67-86.

Bukaciński D., Bukacińska M., Buczyński A., 2012, Co zagraża ptakom środkowej Wisty: diagnoza, skutki i czynne dziatania ochronne, in: Pająkowski J. (ed), „Ochrona przyrody i dziedzictwa kulturowego Doliny Dolnej Wisły", T. 1., Wyd. Zespół Parków Krajobrazowych Chełmińskiego i Nadwiślańskiego, Towarzystwo Przyjaciół Dolnej Wisły, Świecie, 77-78.

Bukaciński D., Bukacińska M., Buczyński A., 2013, The impact of hydrotechnical facilities on island avifauna: a case study of the middle Vistula River, Studia Ecologiae et Bioethicae, 11, 93-109.

Bukaciński D., Bukacińska M., Mastalerz E., 2015a, Presja człowieka na przyrodę środkowej Wisty: liczba i rozmieszczenie ludzi oraz formy ich aktywności na rzece w okresie rozrodu ptaków. Studia Ecologiae et Bioethicae 13, 143-177.

Bukaciński D., Bukacińska M., Zieliński P., 2015b, Śmieszka Chroicocephalus ridibundus, in: Chylarecki P., Sikora A., Cenian Z., Chodkiewicz T. (eds), „Monitoring ptaków lęgowych. Poradnik metodyczny", Wyd. GIOŚ, Warszawa, 266-274.

Bukaciński D. Keller M., Buczyński A., Bukacińska M., 2017, Awifauna legowa koryta środkowej Wisty w roku 2009: zmiany liczebności i rozmieszczenia w ciagu ostatnich 36 lat, in: Keller M., Kot H., Dombrowski A., Rowiński P., Chmielewski S.,
Bukaciński D. (eds) „Ptaki środkowej Wisły”, Wyd. M-ŚTO, Pionki, 31-97.

Chylarecki P., 2007, Sieweczka obrożna Charadrius hiaticula, in: Sikora A., Rohde Z., Gromadzki M., Neubauer G., Chylarecki P. (eds), „Atlas rozmieszczenia ptaków lęgowych Polski 1985-2004", Bogucki Wyd. Nauk., Poznań, 192-193.

Chylarecki P., 2015a, Sieweczka obrożna Charadrius hiaticula, in: Chylarecki P., Sikora A., Cenian Z., Chodkiewicz T. (eds), „Monitoring ptaków lęgowych. Poradnik metodyczny", Wyd. GIOŚ, Warszawa, 230-234.

Chylarecki P., 2015b, Rybitwa białoczelna Sternula albifrons, in: Chylarecki P., Sikora A., Cenian Z., Chodkiewicz T. (eds), „Monitoring ptaków lęgowych. Poradnik metodyczny”, Wyd. GIOŚ, Warszawa, 307-311.

Chylarecki P., Bukaciński D., Dombrowski A., Nowicki W., 1995, Awifauna, in: Gacka-Grzesikiewicz E. (ed), „Korytarz ekologiczny doliny Wisły. Stan funkcjonowanie - zagrożenia", Wyd. IUCN Poland, Warszawa, 79-124.

Chylarecki P., Chodkiewicz T., Neubauer G., Sikora A., Meissner W., Woźniak B., Wylęgała B., Ławicki Ł., Marchowski D., Betleja J., Bzoma S., Cenian Z., Górski A., Korniluk M., Moczarska J., Ochocińska D., Rubacha S., Wieloch M., Zielińska M., Zieliński P., Kuczyński L., 2018, Trendy liczebności ptaków $w$ Polsce, Wyd. GIOŚ, Warszawa.

Drzyzga M., 2015, Wptyw czynnej ochrony na efekty lęów u mew i rybitw, Praca magisterska, Ochrona Środowiska, Wydział Filozofii Chrześcijańskiej UKSW, Warszawa.

Frantham R., Ballou J.D., Briscoe D.A., 2010, Introduction to Conservation Genetics, 2nd Edition, Cambridge University Press, Cambridge.

Grabowska M., 2017, Ekologia rozrodu rybitwy rzecznej Sterna hirundo na wyspach wiślanych w latach 2016-2017, Praca magisterska, Ochrona Środowiska, Wydział Filozofii Chrześcijańskiej UKSW, Warszawa.

Haig S.M., Ballou J.D., Derrickson S.R., 1990, Management options for preserving genetic diversity: reintroduction of Guam Rails to wild, Conservation Biology, 4, 290-300.

Jaszewski B., 2016, Biologia i ekologia rozrodu mewy śmieszki na terenie środkowej Wisty, Praca magisterska, Ochrona Środowiska, Wydział Filozofii Chrześcijańskiej UKSW, Warszawa. 
Keller M., Chylarecki P., Nowicki W., 1998, Przyrodnicze podstawy opracowania optymalnej koncepcji zagospodarowania obszaru doliny Wisty na odcinku od ujścia Pilicy do ujścia Narwi. Inwentaryzacja awifauny legowej $w 1998$ r., Raport dla Instytutu Geografii i Przestrzennego Zagospodarowania PAN, Warszawa.

Keller M., Bukaciński D., Piotrowska M., Wójciak J., 1999, Ocena stanu awifauny legowej doliny Wisty na odcinku od ujścia Pilicy do ujścia Sanu, Raport dla Instytutu Geografii i Przestrzennego Zagospodarowania PAN, Warszawa.

Kot H., Dombrowski A., Bukaciński D., 2017, Zagrożenia dla ptaków środkowej Wisty oraz ich siedlisk, in: Keller M., Kot H., Dombrowski A., Rowiński P., Chmielewski S., Bukaciński D. (eds), „Ptaki środkowej Wisły”, Wyd. M-ŚTO, Pionki, 683-689.

Nowak S., Mysłajek R.W., 2006, Poradnik ochrony zwierzat hodowlanych przed wilkami, Wyd. Stowarzyszenie dla Natury WILK, Twardorzeczka.

Nowak S., Mysłajek R.W., Okarma H., Śmietana W., 2005, Analiza dotychczasowych rodzajów i rozmiaru szkód wyrzadzanych przez wilki oraz stosowanie metod rozwiazywania sytuacji konfliktowych, Wyd. IOP, Kraków.

Pikulska A., 2017, Wptyw drapieżnictwa wybranych ssaków na wyspowe populacje mewy siwej i śmieszki na odcinku środkowej Wisty, Praca magisterska, Ochrona Środowiska, Wydział Filozofii Chrześcijańskiej UKSW, Warszawa.

Różycki A.Ł., 2014, Fenologia rozrodu i produkcja jaj mew: uwarunkowania $i$ konsekwencje $w$ warunkach środkowej Wisty, Rozprawa doktorska, Wydział Biologiczno-Chemiczny, Uniwersytet w Białymstoku, Białystok.
Sikora A., Rohde Z., Gromadzki M., Neubauer G., Chylarecki P. (eds), 2007, Atlas rozmieszczenia ptaków lęgowych Polski 1985-2004, Bogucki Wyd. Nauk., Poznań.

Spottiswoode C., Moller A.P., 2004, Genetic similarity and hatching success in birds, Proceedings of Royal Society London B, 271, 267-272.

Sruoga A., Butkauskas D., Prakas P., Paulauskas A., 2006, Evaluation of the genetic structure of the breeding Common Tern (Sterna hirundo) population by means of microsatellite markers, Biologija, 1 , 47-32.

Śmietana W., 200o, Zabezpieczanie zwierzat gospodarczych przed atakami wilków przy użyciu ogrodzeń elektrycznych, Wyd. IOP, Kraków.

Westmeier, R.L., 1991, Successful exchange of praire-chicken eggs between nests in two remnant populations, Wilson Bulletin, 103, 717-720.

Wilk T., Jujka M., Krogulec J., Chylarecki P. (eds), 2010, Ostoje ptaków o znaczeniu międzynarodowym $w$ Polsce, Wyd. OTOP, Marki.

Zalewski A., Brzeziński M., 2014, Norka amerykańska. Biologia gatunku inwazyjnego, Wyd. Instytutu Biologii Ssaków PAN, Białowieża.

Zielińska M., Zieliński P., Bukaciński D., Bukacińska M., 2015, Mewa czarnogtowa Larus melanocephalus, in: Chylarecki P., Sikora A., Cenian Z., Chodkiewicz T. (eds), „Monitoring ptaków lęgowych. Poradnik metodyczny", Wyd. GIOŚ, Warszawa, 279-285

(Web-o1) dailymail.co.uk Alpaki jak psy pasterskie: bronią owiec przed drapieżnikami https://tvnmeteo.tvn24.pl/informacje-pogoda/ciekawostki,49/ alpaki-jak-psy-pasterskie-bronia-owiec-przed-drapieznikami,83073,1,o.html, dostęp: 10.04.2018 


\section{Zagrożenia i czynna ochrona ptaków koryta rzeki: postulaty do strategii ochrony awifauny Wisły Środkowej}

\section{Streszczenie}

W ciągu ostatnich 34 lat mocno zmieniała się struktura zagrożeń dla ptaków siewkowych Charadriiformes zasiedlających wyspy w korycie Wisły, przede wszystkim mew, rybitw i sieweczek. Podczas gdy w latach 1985-1994 głównymi zagrożeniami dla lęgów były wezbrania wód, drapieżnictwo wrony Corvus corone cornix i sroki Pica pica, a lokalnie również niekontrolowany wypas zwierząt hodowlanych, to w latach 2005-2014 były nimi przede wszystkim presja norki amerykańskiej Neovision vision i lisa Vulpes vulpes oraz masowe wyroje meszek (krwiopijne muchówki z rodziny Simuliidae). Obecność tych zagrożeń prowadziła do blisko zerowego sukcesu lęgowego i wzmożonej śmiertelności ptaków dorosłych na lęgowiskach. W efekcie nastąpił gwałtowny spadek liczebności większości gnieżdżących się tam gatunków mew, rybitw i sieweczek. W 2015-2018 obok drapieżnictwa wcześniej wymienionych ssaków do kluczowych zagrożeń należały: presja zdziczałych kotów i psów oraz coraz częstsza i coraz bardziej masowa obecność ludzi na wyspach, zwłaszcza zmotoryzowanych.

W obliczu sytuacji grożącej wyginięciem najpierw mewy siwej Larus canus, a później również innych gatunków ptaków, w latach 2005-2006 rozpoczęliśmy program czynnej ochrony zagrożonych gatunków wysp środkowej Wisły. Obejmował on (a) redukcję liczebności norki amerykańskiej (głównie poprzez odłowy w pułapki i eutanazję) i lisa (głównie poprzez odstrzał), (b) neutralizowanie obecności tych drapieżników oraz zwierząt hodowlanych w pobliżu lęgowisk poprzez ogrodzenia elektryczne (dla dużych agregacji gniazd) oraz poprzez zabieg włączający wykorzystanie inkubatorów i drewnianych atrap jaj (dla gniazd pojedynczych i mniejszych agregacji), (c) odnawianie siedlisk lęgowych poprzez usuwanie podrostu wierzbowo-topolowego i klonu jesionolistnego Acer negundo, a w przypadku mewy siwej również (d) zwiększanie różnorodności genetycznej w obrębie kolonii lęgowych poprzez wzajemną wymianę lęgów między gniazdami oddalonymi od siebie niemniej niż kilkanaście kilometrów.

Najważniejszym postulatem, kluczowym dla powodzenia całego programu ochrony zagrożonych gatunków koryta rzeki jest prowadzenie czynnych działań ochronnych w sposób kompleksowy i co najważniejsze nieprzerwanie jeszcze przez co najmniej pięć lat (do roku 2023), optymalnie przez całą dekadę (2019-2028). Obok działań ochronnych niezbędne też będzie prowadzenie monitoringu przyrodniczego, który powinien obejmować (a) zmiany liczebności i rozmieszczenia najważniejszych gatunków ptaków koryta rzeki, (b) ocenę sukcesu lęgowego i śmiertelności ptaków dorosłych na lęgowiskach, oraz (c) zmiany liczebności i rozmieszczenia drapieżnych ssaków w pobliżu najważniejszych lęgowisk ptaków. Wydaje się też, że jednym z bardzo ważnych zadań na najbliższe lata będzie przeciwstawienie się wznowieniu planów kompleksowej regulacji środkowego odcinka rzeki, co bezpowrotnie zniszczyłoby ten unikalny już w skali światowej ekosystem.

\section{Stowa kluczowe}

Wisła Środkowa, mewy i rybitwy, aktywna ochrona 